\title{
Da Acumulação de Cargos
}

\author{
Berredo de Menezes
}

$\mathrm{P}$

oucns vêzes, na história de nossa vida pública, tivemos a oportunidade de examinar uma obra de natureza jurídica que fôsse, ao mesmo tempo, persuasiva, agradável e motivadora. E tôdas estas qualidades, sem discrepância, nós encontramos, com ind sfarçável e confortadora surprêsa, neste memorável trabalho - Da Acumulaçào de Cargos (Histórico e Regime Vigente) - do eminente publicista patrício, Dr. Corsindio Monteiro da Silva. editado, em boa hora, pela Universidade Federal do Rio Grande do Sul.

O assunto de que se ocupa a obra, complexo por excelência, constitui, para a grande ma oria dos que ousam enveredar pelos meandros às vêzes inextricáveis das Ciências Jurídicas, matéria insipida e, não raramente, até odienta, por contrariar interêsses de pessoas a que estamos ligados, quase sempre, por laços indestrutiveis de amizade ou parentesco, ou ainda - o que é comum - por contravir, de frente, as nossas próprias conventências. Dai, por certo, a nossa pobreza bibliográfica sôbre esta matéria tão relevante e que, como bem nos ilumina e orienta, com invulgar singeleza e maestria, o insigne jurista, tanto tem preocupado como desafiado a arqúcia dos nossos governantes, desde os tempos do Brasil Colônia.

Do ponto-de-vista científico, o Dr. Corsíndio Monteiro da Silva, sem sombra de dúvida, realizou um trabalho de fôlego, revelando-se um pesquisador dos mais criteriosos e abnegados, no que concerne a êste instituto árido de nosso Direito Administrativo. E a sua obra, neste particular, além de incomparável, ve o preencher uma lacuna em nossas letras juridicas, pois, como nos adverte, na "Apresentação" do livro, o não menos admirável Darcy Azambuja, o ilustre autor, "divulgando documentos inéditos, traçando o roteiro histórico do instituto da acumulação, estabeleceu bases de direito, de justiça, e de interêsse público, contribuindo decisivamente para estabelecer um critério uniforme na 
soluçâo de múltiplas questões que, ainda dentro dêste já secular problema, surgem diàriamente nas relaçōes entre o Estado e seus servidores."

Mas o que também encanta e surpreende, em todo o tluir da obra, é a delicadeza do estilo! Com efeito, antes da sua leitura (e, em particular, da "Breve Notícia Histórica"), tem-se a impressão de que se vai enfrentar uma discussão acadêm:ca, dessas que proliferam em nossas estantes juridicas. E aí é que está a surprêsa: o Dr. Corsindio Monteiro da Silva, num autêntico milagre de linguagem, consegue transformar em sabor de romance um trabalho eminentemente científico, aliciando-nos, com tirocinio e arte, a nunca mais despregarmos os olhos de sua "Breve Notícia H:stórica", enquanto não lhe chegamos ao fim.

Após esta primeira parte, de invulgar originalidade no gênero, deleita-nos novamente o conceituado jurista com uma série primorosa de elucidativos e eruditos pareceres, emitidos, todos, no seu respeitável mister de membro dos mais brilhantes e cultos da Comissão de Acumulação de Cargos, do DASP, onde se tem revelado, outrossim, como um autêntico e edificante exemplo de dedicação e zêlo pelas coisas desta Nação.

Seria ocioso acrescentarmos que us pareceres do Dr. Cor sindio Monteiro constituem matéria-prima obrigatória e imprescindivel aos que se dedicam ao estudo do Direito Administrativo e, em especial, ao do instituto da acumulação.

Por via de conseqüência, pois, esta sua magnifica obra, por muito tempo ainda, deverá ser indicada como fonte indispensável e basilar para quantos pretenderem familiarizar-se com êste capítulo importantíssimo e secular de nosso Direito Público.

Para concluir, não poderíamos deixar sem relêvo a felicidade com que se houve o Dr. Corsindio Monteiro da Silva em ultimar o seu livro com um ntilissimo ementário de jurisprudência administrativa (sôbre acumulações consideradas lícitas e ilícitas), pois se a obra, até ali, só merecia encômios, esta última parte, de profundo alcance prático, emprestou-lhe a configuração de um bloco monolítico, difícil de ser superado em conteúdo, originalidade e erudição.

Berredo de Menezes - Professor de Direito Público da Universidade Federal do Espirito Santo - "A Tribuna" - de Vitória, Estado do Espirito Santo - 17-10-1967. 